\title{
PENGEMBANGAN E-MODUL BERBASIS PROYEK UNTUK MATA KULIAH FOTOGRAFI DI JURUSAN TEKNOLOGI PENDIDIKAN FAKULTAS ILMU PENDIDIKAN UNDIKSHA
}

\author{
Alexander Hamonangan Simamora \\ Jurusan Teknologi Pendidikan, Fakultas Ilmu Pendidikan, Universitas Pendidikan Ganesha \\ e-mail : alexandersimamora88@gmail.com \\ I Komang Sudarma \\ Jurusan Teknologi Pendidikan, Fakultas Ilmu Pendidikan, Universitas Pendidikan Ganesha \\ e-mail : sudarmadede@gmail.com \\ Dewa Gede Agus Putra Prabawa \\ Jurusan Teknologi Pendidikan, Fakultas Ilmu Pendidikan, Universitas Pendidikan Ganesha \\ e-mail :dw_prabawa@yahoo.co.id
}

\begin{abstract}
Abstrak
Penelitian pengembangan yang dilakukan memiliki tujuan untuk menghasilkan electronic modul (e-modul) untuk mata kuliah fotografi di Jurusan Teknologi Pendidikan FIP Undiksha. Tujuan khusus yang ingin dicapai melalui penelitian ini adalah untuk: (1) mendeskripsikan prosedur pengembangan e-modul; dan (2) mendeskripsikan tanggapan ahli, dosen pengampu mata kuliah dan mahasiswa terhadap buku ajar yang dikembangkan. E-modul yang dikembangkan mengacu pada model pengembangan pembelajaran Dick, Carey, dan Carey (2005) yang memiliki 10 langkah. Adapun kesepuluh langkah tersebut, yaitu 1) tahap identifikasi kebutuhan dan menentukan tujuan umum, 2) melakukan analisis pembelajaran, 3) mengidentifikasi perilaku dan karakteristik awal peserta didik, 4) menulis tujuan pembelajaran khusus , 5) menyusun alat penilaian hasil belajar, 6) menyusun strategi pembelajaran, 7) memilih dan mengembangkan materi pembelajaran, 8) merancang dan melaksanakan evaluasi formatif, 9) merancang dan melaksanakan evaluasi sumatif, 10) revisi. Modul yang telah melewati tahap pengembangan selanjutnya perlu dievaluasi. Model evaluasi yang digunakan evaluasi formatif dari Dick, Carey, dan Carey (2005). Tahapan tersebut meliputi: (1) validasi ahli; (2) uji coba perorangan yang melibatkan tiga orang mahasiswa, dan (3) uji coba kelompok kecil yang melibatkan 12 orang mahasiswa. Selama evaluasi formatif digunakan instrumen berupa kuesioner. Data yang telah terkumpul, selanjutnya dianalisis menggunakan teknik analisis deskriptif. E-modul telah berhasil dikembangkan menggunakan model Dick and Carey. E-modul selanjutnya siap divalidasi oleh dua orang ahli yaitu ahli isi sekaligus ahli desain dan ahli media. Setelah itu akan diujicobakan di lapangan untuk mengetahui tanggapan mahasiswa tentang e-modul yang dikembangkan. Berdasarkan penilaian ahli, bahwa validitas isi e-modul memperoleh skor 92 yang berada pada kategori sangat baik, validitas desain pembelajaran memperoleh skor 93,91 yang berada pada kategori sangat baik, dan aspek media memperoleh skor 90 yang berada pada kategori sangat baik. Berdasarkan penilaian mahasiswa bahwa e-modul berada pada kategori baik dengan skor 85,77.
\end{abstract}

Kata Kunci: E-modul, fotografi

\begin{abstract}
The research has purpose to produce module Electronic (E-Module) For Photogrphy subject of Education Technploghy program in Education Faculty of Undiksha the specific purpose of the research are: (1) Describing Procedure of E-Module development; and (2) Describing an exepert, the lecturer of subject, and university students to the book which developed. E-Module was developed by based on learning strategy dick carey and carey (2005) which has 10 steps they are: 1) Identification step of needs and decide the general purpose 2) doing learning analysis, 3) Identifying the studens prior attitude and character. 4) Writing the specific purpose of learning,5) arranging evaluation instrument of learning result, 6) arranging learning strategy, 7) choosing and developing learning material, 8) planning and Implementing formative evaluation, 9) planning and implementing summative evaluation, 10) revision, The module which passing developmentstep that needs to evaluate. The evaluation module used was formative evaluation by dick, carey, and carey, (2005). The steps are; (1) exepert validation, (2) experiment personally involved by three students, and (3) exeperiment in small group involved by 12 students. The instruments were used during formative evaluation. The collected datas were analyzed by using descriptive analysis. The module developed successfully by using the strategy dick and design expert are. E-module was validated by two exepert. Such as content exepert all at once as design, exepert and media expert, after that is was. Experiment to know students responses to the E-Module developed based on the expert evaluation, the content validation of E- Module got 92 score involved very good category. The validity of learning design got 93,91 score involved very good
\end{abstract}


category, and media aspect90 score Involved very good category. Based on the students evaluation that E-Module involved on good category with 85,77 score.

Keyword : E-Modul, Photography

\section{PENDAHULUAN}

Pembelajaran merupakan suatu sistem. Kualitas proses dan hasil belajar dapat dipengaruhi oleh kualitas komponen-komponen dalam pembelajaran. Suparman (2012) menyatakan komponen pembelajaran terdiri atas: a) peserta didik, b) proses pembelajaran, c) lulusan dengan kompetensi yang diharapkan, d) pendidik, e) kurikulum, dan f) bahan pembelajaran. Komponen sistem pembelajaran yang turut mempengaruhi proses dan hasil belajar adalah bahan ajar (instructional materials). Bahan ajar merupakan seperangkat bahan yang memuat materi atau isi pembelajaran yang didesain untuk mencapai tujuan pembelajaran (Sungkono, 2003).

Ada berbagai jenis bahan ajar salah satunya adalah modul. Menurut Asyhar (2011: 155) modul ajar adalah salah satu bentuk bahan ajar berbasis cetak yang dirancang untuk belajar secara mandiri oleh peserta didik karena itu modul dilengkapi dengan petunjuk untuk belajar sendiri. Modul memiliki struktur yang lebih lengkap jika dibandingkan dengan buku ajar maupun buku teks. Namun keberadaan modul masih terbatas terutama untuk mata kuliah fotografi di Jurusan Teknologi Pendidikan. Buku ajar cetak yang digunakan selama ini memiliki banyak keterbatasan. Pertama, pesan gambar pada buku ajar masih dicetak hitam putih. Salah satu karakteristik buku ajar fotografi adalah memuat gambar lebih banyak dari pada buku ajar pada umumnya. Apabila dikaji dari aspek desain pesan, penggunaan gambar hitam putih tidak dibenarkan. Namun apabila dicetak berwarna akan memberatkan mahasiswa dari segi biaya cetak. Kedua, hasil observasi awal menunjukkan bahwa mahasiswa belum memanfaatkan buku ajar secara optimal. Mahasiswa lebih banyak membaca buku ajar ketika akan mendapat tugas presentasi maupun mengerjakan tugas-tugas lainya. Ini berkaitan dengan kurangnya interaktivitas buku ajar terutama soalsoal latihan. Selama ini kelemahan soal-soal latihan pada buku ajar khususnya yang pilihan ganda tidak segera memberikan feedback. Feedback baru dapat diberikan jika sudah dilakukan kuliah tatap muka. Gee (2005) mengatakan bahwa dengan adanya umpan balik segera dapat membantu pembelajar mengetahui kemajuan belajarnya. Umpan balik dapat memperkuat apa yang telah dipelajari dan juga dapat memperbaiki kesalahpahaman.

Selain keterbatasan pada buku ajar, permasalahan juga ditemukan dari kebiasaan mahasiswa membaca. Berdasarkan hasil survei pada mahasiswa Teknologi pendidikan semester II dan IV yang berjumlah 47 orang pada bulan Maret 2017 diperoleh data sebagai berikut.

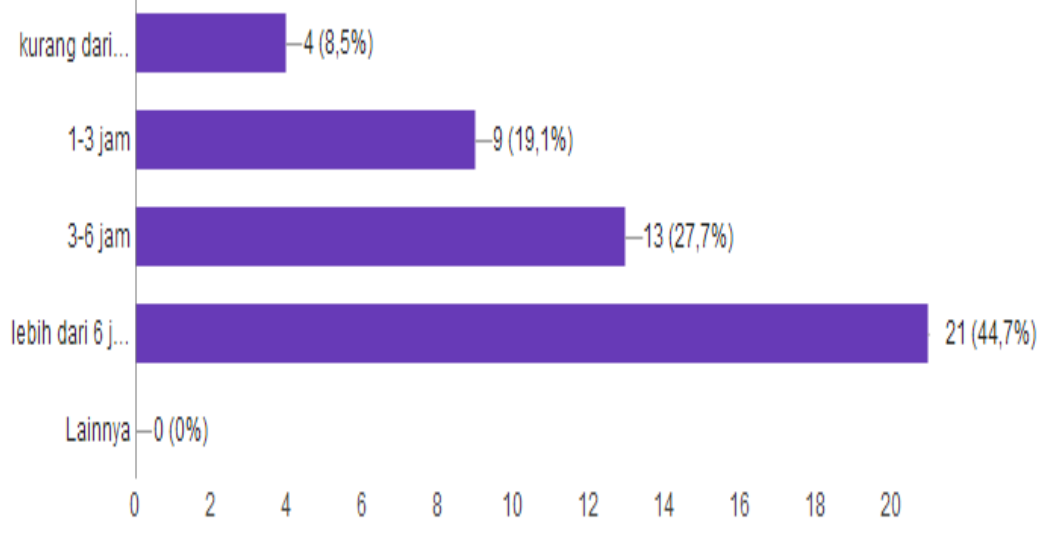

Gambar 1.1 Lama Penggunaan Smartphone di Kalangan Mahasiswa 


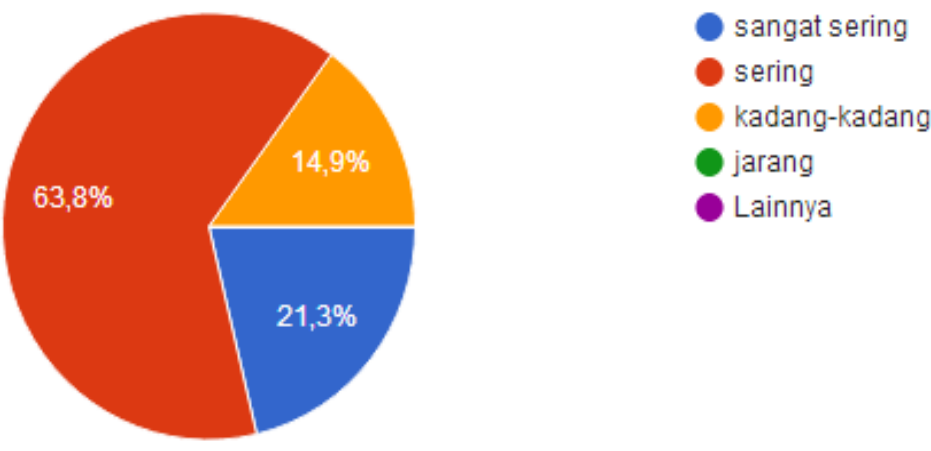

Gambar 1.2 Persentase Mahasiswa Membaca Bacaan Digital

Lebih dari 6 jam per hari mahasiswa aktif menggunakan smartphone. Ini mengindikasikan bahwa mahasiswa lebih tertarik membaca bacaan digital. Selanjutnya, sebanyak 63,8\% mahasiswa lebih sering membaca bahan bacaan digital, melalui media sosial maupun web. Hasil survei tersebut mengindikasikan bahwa perkembangan teknologi telah mengubah kebiasaan mahasiswa dari membaca bahan ajar cetak ke bacaan digital. Mengingat bacaan digital dapat diakses secara mudah dan praktis. Dengan demikian bahwa perlu dikembangkan bahan ajar digital untuk mengikuti perkembangan teknologi informasi saat ini.

Mata kuliah fotografi merupakan mata kuliah yang memiliki tugas-tugas praktik lebih banyak. Kata Fotografi berasal dari bahasa Inggris yaitu "Photographic". Kata Photographic terdiri dari dua unsur kata "Photo" dan "Graphic". Photo yang artinya foto atau potret dan kata graphic yang artinya tulisan dengan atau tentang gambar. Soelarko, (1984) berpendapat bahwa istilah fotografi mengarah pada teknik dan pengetahuan foto.

Berdasarkan hasil pengamatan bahwa mahasiswa ternyata lebih termotivasi mengerjakan tugas yang memiliki manfaat nyata dan lebih kontekstual. Namun pada buku ajar yang selama ini digunakan masih sangat sedikit tugas-tugas proyek. Pada abad ke-21 keterampilan penyelesaian proyek secara kooperatif dan kolaboratif sangat diperlukan dalam dunia kerja.

Adanya beberapa kekurangan pada buku ajar fotografi, masalah dalam proses pembelajaran, dan perkembangan teknologi informasi dan komunikasi (TIK) maka dipandang perlu mengembangkan sebuah elektronik modul (e-modul) berbasis proyek. E-modul merupakan upaya untuk mengantisipasi perkembangan teknologi dari bahan ajar cetak ke bahan ajar digital. Mengingat perkembangan saat ini, mahasiswa lebih sering membaca melalui smartphone maka e-modul merupakan suatu kebutuhan di era digital saat ini. E-modul ini memiliki kelebihan dengan modul cetak. Pertama, e-modul dapat diakses secara online baik melalui laptop maupun smartphone. Mengingat karakteristik mata kuliah fotografi adalah praktik ke lapangan (hunting) maka akan lebih praktis kalau mahasiswa difasilitasi e-modul. Kedua, e-modul memfasilitasi mahasiswa belajar secara mandiri. Mahasiswa dapat mengakses e-modul kapan pun dan dimanapun dengan menggunakan smartphone. Gambar yang disajikan pada modul semua berwarna dengan resolusi tinggi sehingga memudahkan mahasiswa menginterpretasikan isi materi. Ketiga, e-modul menyediakan soal-soal dan quis yang interaktif sehingga dapat mengukur tingkat penguasaan materi di akhir kegiatan belajar. Ini merupakan upaya untuk mengatasi kelemahan modul cetak, dimana kunci jawaban dapat dilihat oleh mahasiswa. Keempat, e-modul memuat sejumlah proyek otentik. Unsur proyek dalam e-modul menuntut mahasiswa bekerjasama dan berkolaborasi untuk menyelesaikan topik-topik proyek yang telah ditentukan. Beberapa keterampilan yang dapat dikembangkan melalui penyelesaian proyek yaitu: 1) keterampilan belajar kelompok, 2) life skills, 3) keterampilan kognitif (mengambil keputusan, berpikir kritis, memecahkan masalah), 4) keterampilan manajemen diri (menetapkan tujuan dan pengorganisasian tugas), 5) mengembangkan sikap positif, 6) self direction, dan 7) meningkatkan rasa percaya diri (Buck Institute for Education, 2012).

Hasil penelitian Alias dan Saedah (2012) menunjukkan bahwa modul efektif untuk pembelajaran terutama yang memiliki gaya belajar visual. Hal ini mengindikasikan bahwa e-modul fotografi yang menyajikan gambar-gambar berwarna akan lebih memberikan daya tarik, memberikan pesan konkret, dan memudahkan mahasiswa memahami jenis-jenis foto dalam teknik fotografi. Berdasarkan pemaparan di atas, maka penting dikembangkan e-modul berbasis proyek untuk mata kuliah fotografi di jurusan Teknologi Pendidikan FIP Undiksha. Berdasarkan latar belakang di atas, dapat diajukan tujuan penelitian, 
yaitu untuk mendeskripsikan prosedur pengembangan buku ajar desain pesan dan mendeskripsikan tanggapan ahli, dosen, dan mahasiswa terhadap e-modul berbasis proyek yang dikembangkan.

\section{METODE PENELITIAN}

Jenis penelitian ini adalah penelitian pengembangan. Borg dan Gall (2003) menyatakan penelitian pengembangan adalah penelitian yang berorientasi untuk mengembangkan dan memvalidasi produk-produk yang digunakan dalam pendidikan. Model pengembangan yang digunakan adalah model Dick and Carey (2005) yang terdiri atas 10 tahap sebagaimana nampak pada Gambar 3.1.

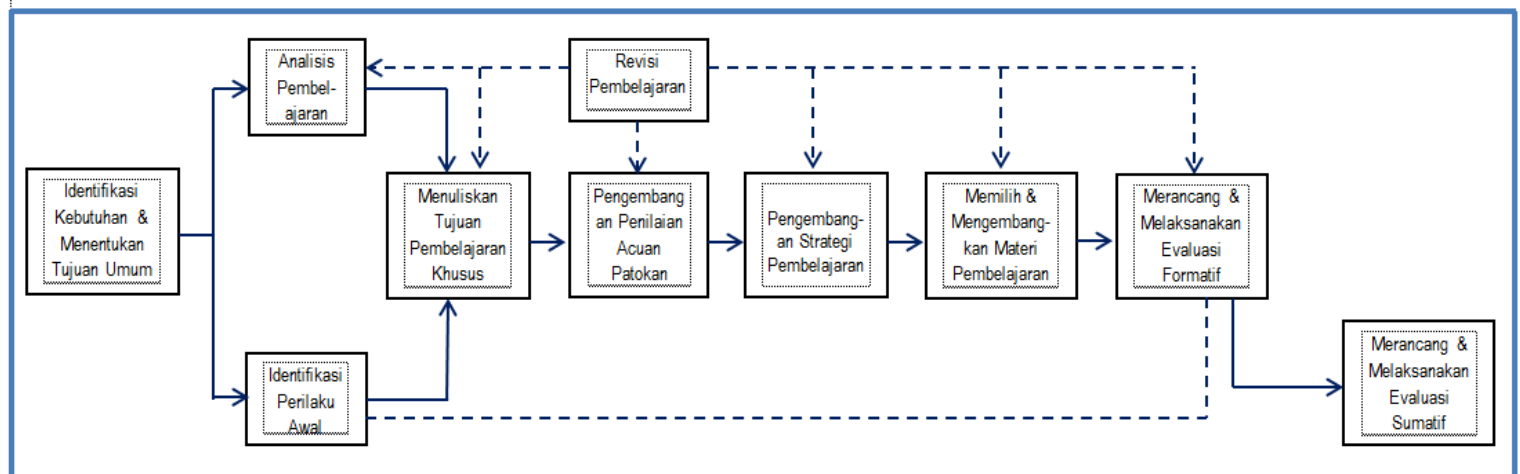

Gambar 3.1 Dick and Carey (2005)

E-modul sebagai hasil pengembangan harus melewati serangkaian uji coba untuk mengetahui tingkat validitasnya. Tingkat validitas buku ajar dapat diketahui melalui hasil analisis review ahli, dosen pengampu mata kuliah, uji perorangan dan uji kelompok kecil. Berikut ini disajikan desain uji coba produk.

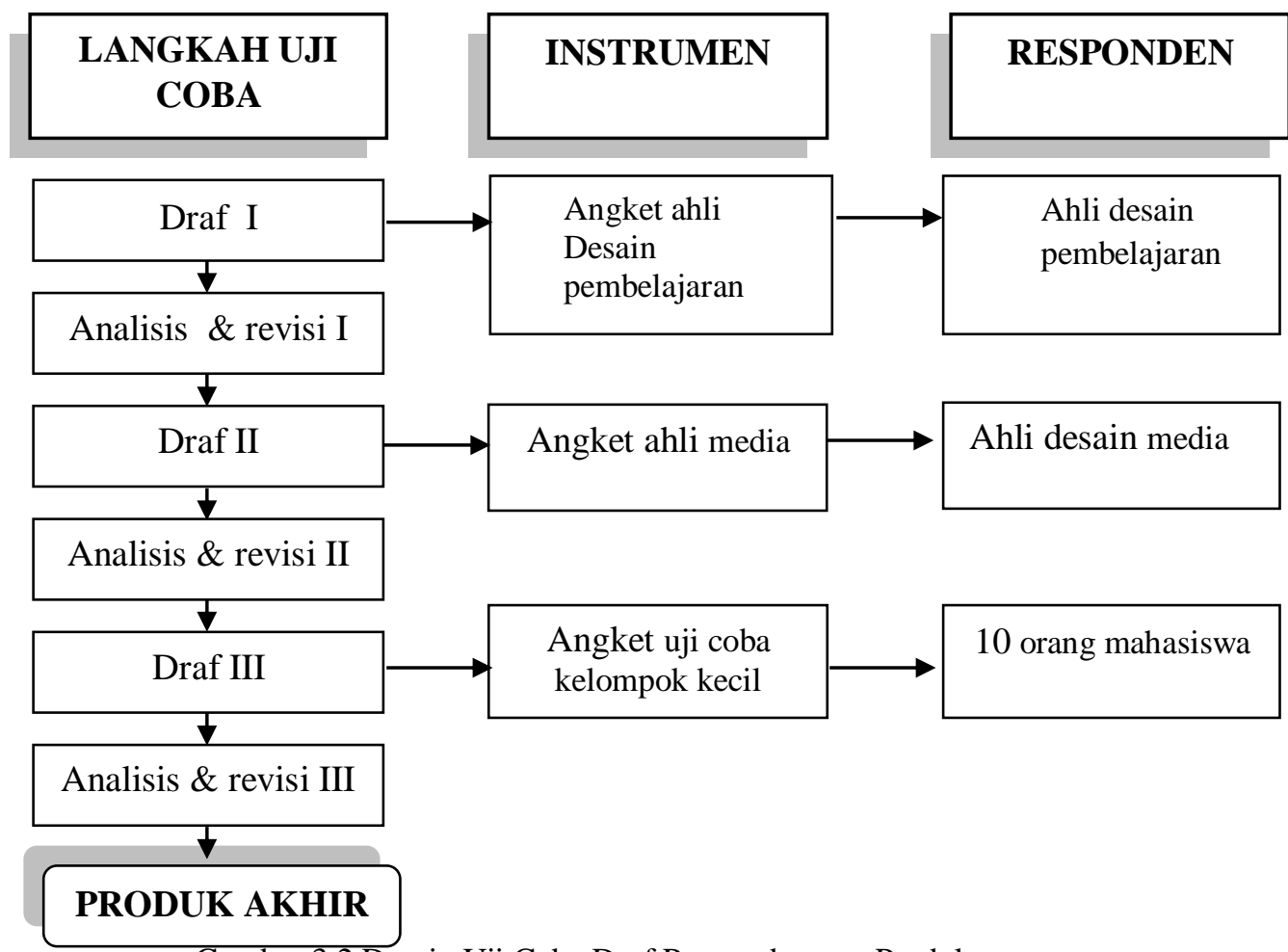

Gambar 3.2 Desain Uji Coba Draf Pengembangan Produk

Data dikumpulkan dengan menggunakan metode observasi dan kuesioner. Metode observasi digunakan pada saat melakukan studi pendahuluan. Kuesioner digunakan untuk memperoleh data dari ahli, penilaian dosen, uji coba perorangan dan uji coba kelompok kecil. Upaya memastikan validitas kuesioner dilakukan kegiatan pembuatan tabel kisi-kisi, dan penulisan instrumen. Data yang telah dikumpulkan menggunakan metode kuesioner selanjutnya dianalisis menggunakan analisis deskriptif kualitatif dan analisis deskriptif kuantitatif. Analisis deskriptif kualitatif digunakan untuk menganalisis 
informasi tentang berupa tanggapan dan pandangan. Metode ini digunakan menganalisis komentar maupun saran para ahli dan responden pada saat uji coba perorangan, dan uji kelompok kecil. Hasil analisis digunakan untuk merevisi rancangan produk pengembangan.

\section{HASIL DAN PEMBAHASAN}

E-modul telah berhasil dikembangkan menggunakan model Dick dan Carey (2005). Berikut dipaparkan hasil pengembangan sesuai model tersebut.

a. Tahap Identifikasi Kebutuhan dan Menentukan Tujuan Umum

Pada tahap ini ditemukan masalah bahwa mahasiswa mengalami kesulitan membangun dan mengimplementasikan pengetahuan atau teori asesmen Fotografi di lapangan. Sehingga masalah ini mendorong untuk mengembangkan sebuah modul ajar yang berorientasi pada penyelesaian sejumlah projek-projek otentik. Projek merupakan wadah konkret untuk mengimplementasikan teori Fotografi di lapangan. Setelah ditemukan masalah, selanjutnya adalah merumuskan kompetensi-kompetensi. Kompetensi yang dimaksud adalah kompetensi umum atau dikenal dengan istilah tujuan instruksional umum. Adapun kompetensi tersebut yaitu: (1) Mahasiswa dapat memahami fotografi dan Karakteristiknya, (2) mahasiswa dapat memahami Kamera dan Asesorisnya, (3) mahasiswa Mengenal Ruang Tajam, Pencahayaan, dan Komposisi, dan (4) mahasiswa dapat menerapkan Teknik-teknik dalam Praktek Pemotretan. Selain menganalisis kompetensi umum pada tahap ini juga dilakukan analisis karakteristik mahasiswa sebagai acuan mengembangkan buku ajar. Pada Tabel 4.1 disajikan hasil analisis karakteristik mahasiswa.

Tabel 4.1 Hasil Analisis Karakteristik Mahasiswa

\begin{tabular}{|c|c|}
\hline Jenis Karakteristik & Hasil \\
\hline 1. Karakteristik Umum & $\begin{array}{l}\text { 1. Sebagian besar mahasiswa berasal dari ekonomi } \\
\text { menengah ke bawah. Sumber belajar yang } \\
\text { diperoleh mahasiswa cenderung didapat dengan } \\
\text { cara fotokopi dengan alasan harga lebih murah. } \\
\text { 2. Mahasiswa sebagian besar tinggal desa. } \\
\text { 3. Dalam satu kelas dominan mahasiswa laki-laki } \\
\text { 4. Usia mahasiswa rata-rata 19-20 tahun. }\end{array}$ \\
\hline 2. Kompetensi & $\begin{array}{l}\text { 1. Mahasiswa familiar menggunakan komputer. } \\
\text { 2. Mahasiswa tidak asing dengan kamera } \\
\text { 3. Mahasiswa memahami tentang perkembangan } \\
\text { dunia fotografi terkini } \\
\text { 4. Mahasiswa memahami teknik foto-foto } \\
\text { sederhana }\end{array}$ \\
\hline 3. Motivasi & $\begin{array}{l}\text { 1. Motivasi intrinsik mahasiswa untuk } \\
\text { mengembangkan diri cukup baik } \\
\text { 2. Motivasi intrinsik cenderung meningkat apabila } \\
\text { perkuliahan lebih banyak praktik dari pada } \\
\text { pemaparan teori } \\
\text { 3. Pengorganisasian mahasiswa dalam kelompok- } \\
\text { kelompok belajar yang efisien menumbuhkan } \\
\text { motivasi eksternal }\end{array}$ \\
\hline 4. Gaya Belajar & $\begin{array}{l}\text { 1. Gaya Penyajian Materi } \\
\text { Secara umum gaya belajar mahasiswa concrete } \\
\text { sequential yaitu mahasiswa menyukai } \\
\text { pengalaman belajar langsung (hands on } \\
\text { experience) yang diorganisasikan secara } \\
\text { sistematis, misalnya dengan menggunakan } \\
\text { latihan dan aktivitas pembelajaran yang } \\
\text { terprogram. } \\
\text { 2. Gaya Pemahaman informasi }\end{array}$ \\
\hline
\end{tabular}


Secara umum mahasiswa memiliki gaya belajar visual. Kecepatan mahasiswa memahami pesan dan informasi dapat efektif jika disampaikan lewat gambar, praktikum, dan demonstrasi.

Hasil analisis kompetensi dan hasil analisis karakteristik mahasiswa dijadikan acuan untuk mengumpulkan materi untuk pembuatan e-modul. Materi dikumpulkan melalui buku-buku, artikel hasil penelitian, sumber di internet, dan pengalaman peneliti mengajar mata kuliah fotografi.

b. Analisis Pembelajaran (Instruksional)

Analisis pembelajaran atau instruksional bertujuan untuk merumuskan kompetensi umum yang telah ditentukan pada tahap 1 kemudian rinci kembali menjadi kompetensi yang lebih khusus. Kompetensi ini sering disebut dengan istilah tujuan instruksional khusus (TIU). Berikut ini adalah hasil analisis instruksional untuk satu kompetensi umum.

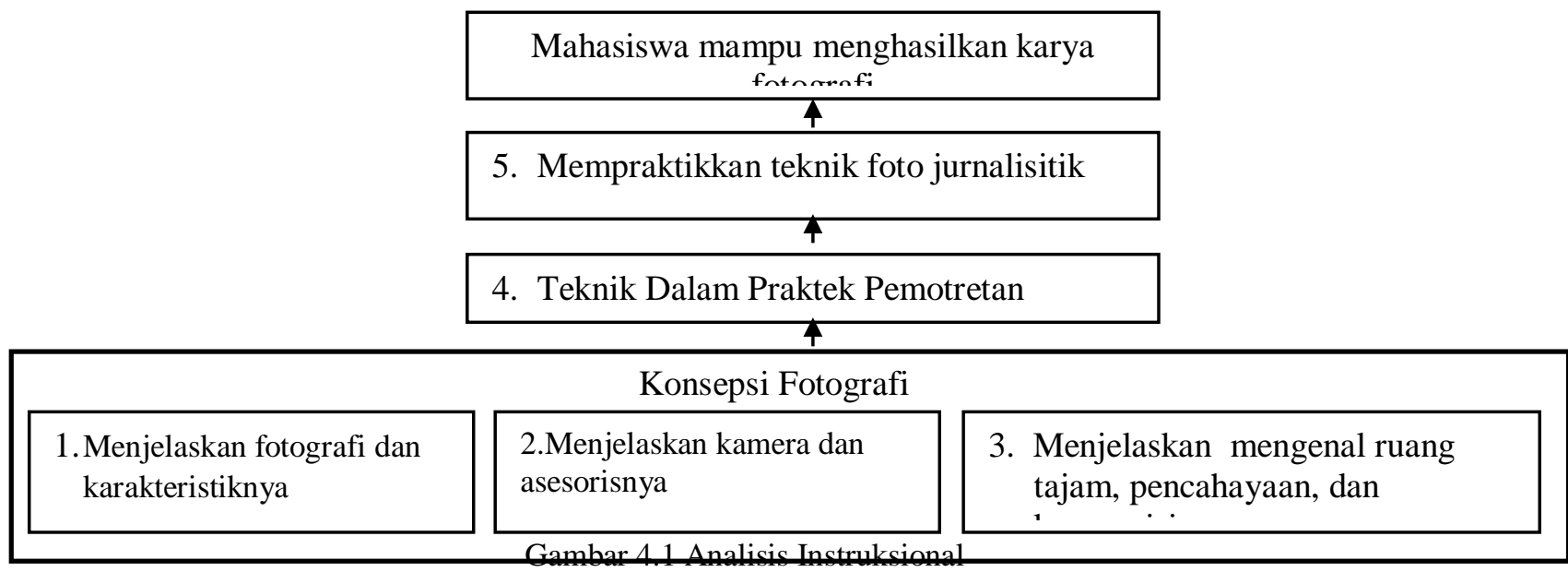

c. Mengidentifikasi Perilaku dan Karakteristik Awal Peserta didik

Karakteristik awal peserta didik diketahui melalui metode observasi. Hasil observasi telah disajikan pada Tabel 4.1.

d. Menyusun Alat Penilaian Hasil Belajar

Penilaian yang digunakan dalam e-modul menggunakan dua metode penilaian, yaitu metode tes dan metode non tes. Jenis metode tes adalah tes uraian sedangkan metode non tes adalah asesmen projek.

e. Menyusun Strategi Pembelajaran

Strategi pembelajaran yang digunakan dalam merancang buku ajar adalah strategi penyampaian pesan. Strategi penyampaian pesan mengadopsi teori desain pesan pembelajaran. Adapun prinsipprinsip desain pesan yang diterapkan dalam menyusun buku ajar yaitu prinsip motivasi, prinsip memori, prinsip persepsi, dan prinsip belajar konsep. Selain itu, beberapa hal lainnya yang digunakan untuk mendesain buku ajar adalah aspek kemenarikan sampul buku, pemilihan jenis dan ukuran huruf yang tepat, desain layout yang menarik, pemilihan warna yang menarik, dan pengaturan banyaknya kata dalam sebuah paragraf.

f. Tahap Pengembangan Materi
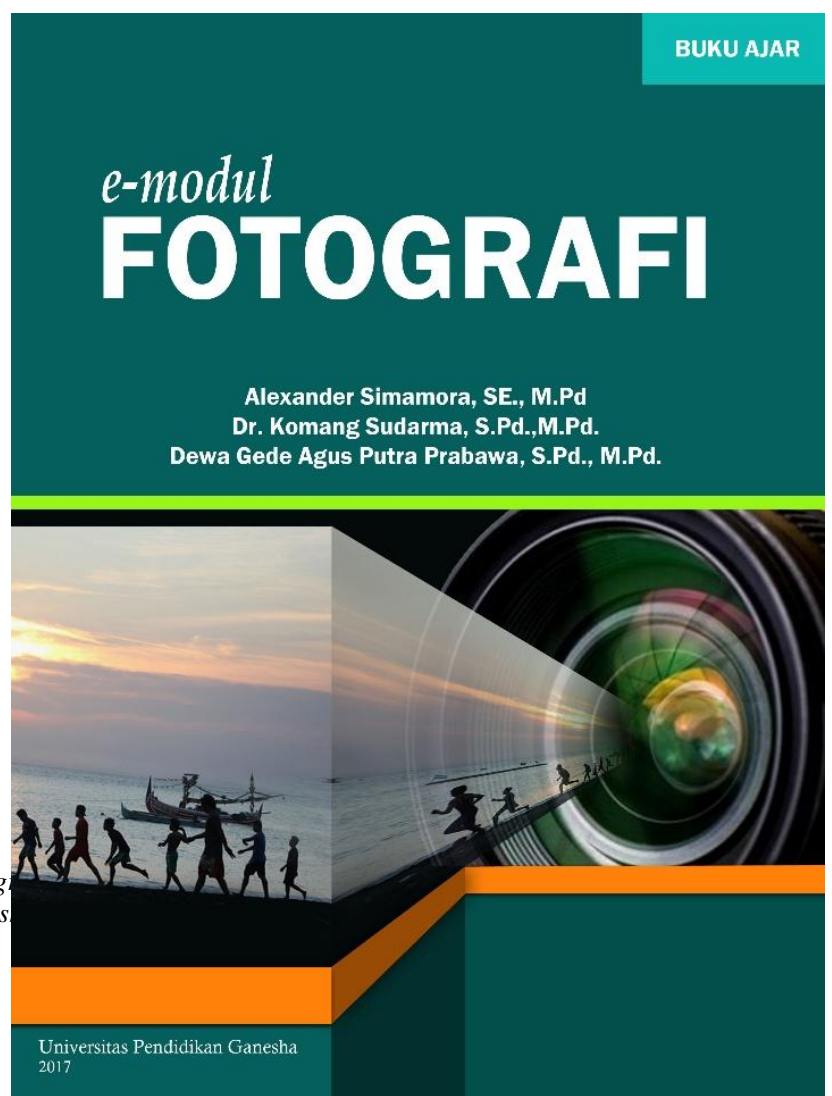
Pada tahap ini e-modul telah disusun berdasarkan hasil analisis instruksional. Proses penyusunan e-modul tentu berdasarkan hasil analisis kebutuhan, ruang lingkup teori fotografi, hasil-hasil penelitian, dan pengalaman peneliti. Materi disajikan menggunakan kata-kata yang komunikatif yang bertujuan agar mahasiswa mudah memahami pesan yang disampaikan. Untuk memudahkan mahasiswa memahami materi, buku ajar juga dilengkapi dengan tabel-tabel, gambar, dan beberapa contoh-contoh yang diperlukan. Pada Gambar 4.2 merupakan tampilan dari pengembangan e-modul.

Validitas e-modul dinilai melalui tiga aspek yaitu validitas isi, validitas desain pembelajaran, dan validitas media pembelajaran. Untuk mengetahui validitas tersebut digunakan dua orang ahli dengan rincian satu orang menilai aspek isi dan aspek desain pembelajaran dan lagi satu ahli menilai aspek media pembelajaran. Berdasarkan penilaian ahli bahwa validitas isi e-modul berada pada kategori sangat baik dengan perolehan persentase $92 \%$. Validitas aspek desain pembelajaran berada pada kategori baik dengan perolehan persentase $93,91 \%$. Validitas aspek media pembelajaran berada pada kategori sangat baik dengan peroleh persentase $90 \%$. Secara visual dapat disajikan pada Gambar 4.3 berikut.

Gambar 4.2 Tampilan Sampul E-modul

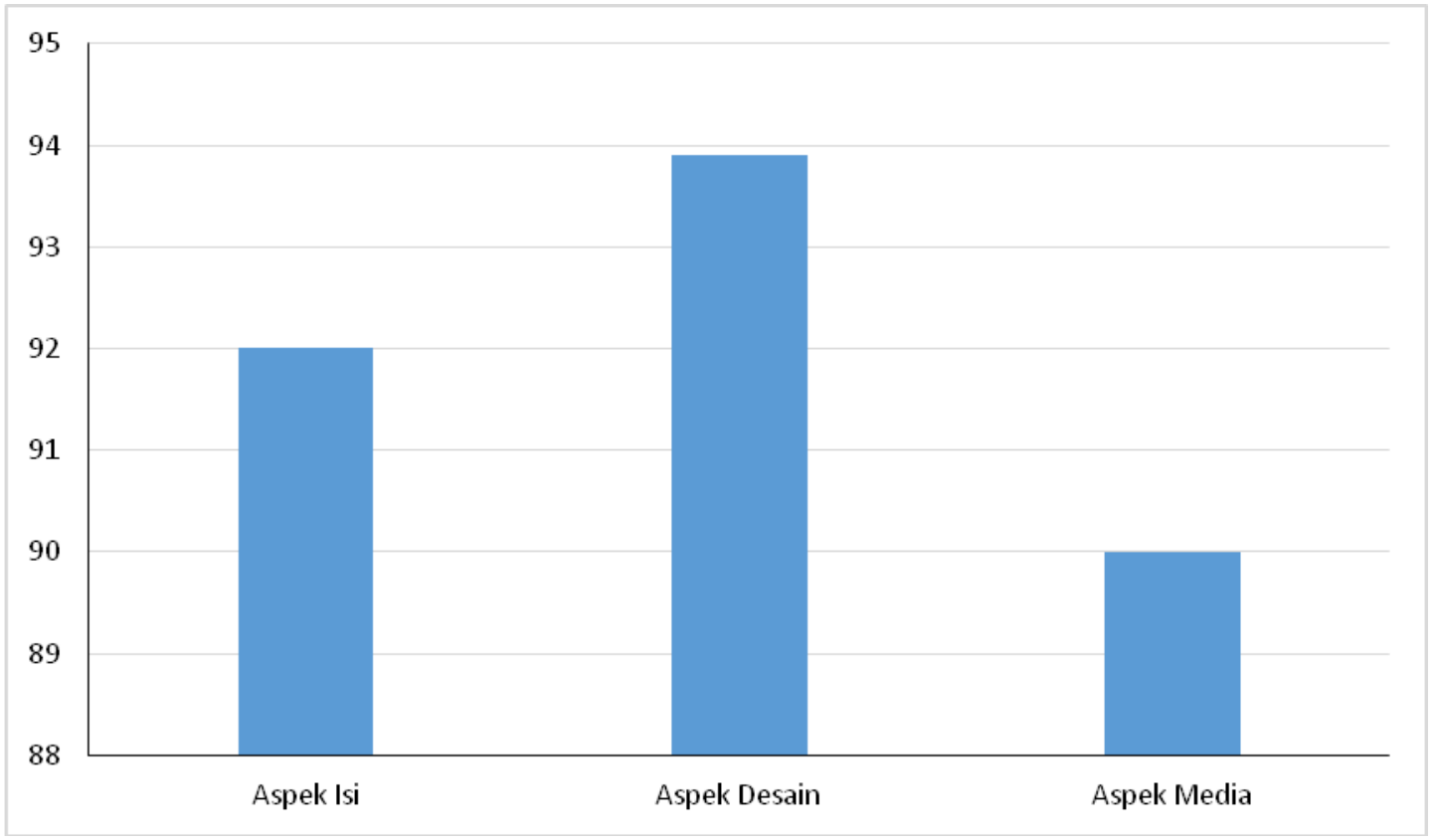


Gambar 4.3 Perolehan Tingkat Validitas Aspek isi, Desain, dan Aspek Media dalam Penilaian eModul Fotografi

Selain validitas tiga aspek tersebut, e-modul juga dinilai oleh mahasiswa yang memberikan penilaian bahwa e-modul berada pada kategori baik dengan perolehan persentase $85,7 \%$. Secara visual penilaian mahasiswa dapat disajikan pada Gambar 4.4 berikut.

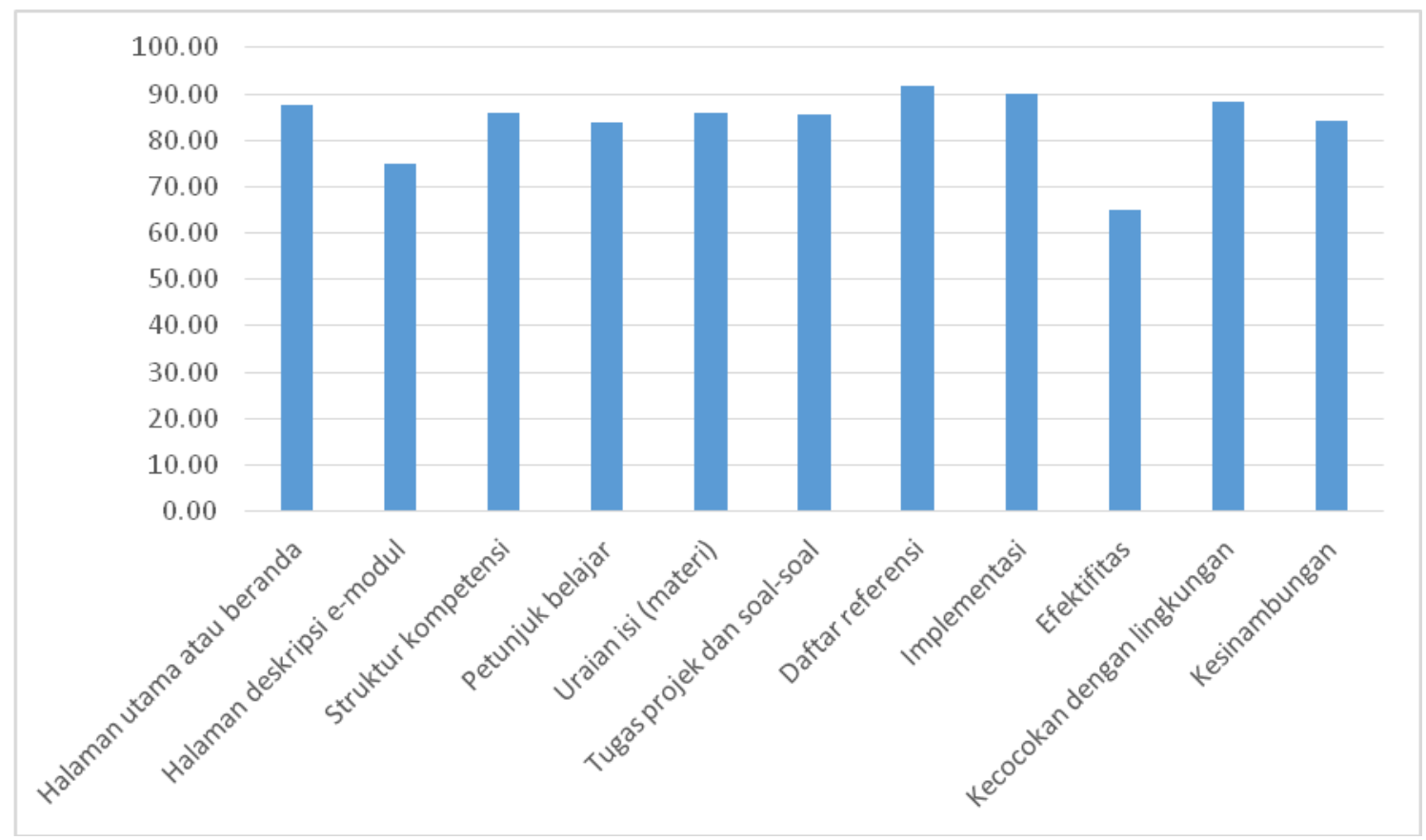

Gambar 4.4 Penilaian E-modul oleh Mahasiswa

E-modul telah berhasil dikembangkan menggunakan model Dick dan Carey. Model ini telah memberikan langkah-langkah sistematis sehingga proses pengembangan lebih optimal dan meminimalkan kesalahan yang terjadi. E-modul yang telah berhasil dikembangkan juga telah divalidasi oleh ahli isi sekaligus ahli desain, dan ahli media pembelajaran.

Berdasarkan penilaian ahli isi bahwa konten e-modul berada pada kategori sangat baik dengan perolehan persentase sebesar 92\%. Peroleh ini tidak terlepas dari beberapa aspek. Pertama, pengetahuan yang disajikan dalam e-modul layak dibelajarkan kepada mahasiswa. Penyusunan isi e-modul merujuk pada buku-buku yang sesuai dengan tuntutan kompetensi mata kuliah fotografi. Pemilihan buku didasarkan pada karakteristik indikator pencapaian kompetensi di setiap modul. Sumber yang dirujuk juga cukup muktahir sehingga relevan diacu. Penulisan isi juga, menggunakan referensi dari artikelartikel dalam jurnal. Isi e-modul juga saling berkaitan dan membentuk alur yang mudah pahami. Urutan penyajian isi dari mudah ke sulit, dari yang diketahui ke yang tidak diketahui, dan dari pengetahuan ke penerapan. Isi e-modul disajikan dengan sistem kegiatan belajar yang secara keseluruhan ada lima modul.

Berdasarkan penilaian ahli isi bahwa konten e-modul berada pada kategori sangat baik dengan perolehan persentase sebesar 92\%. Peroleh ini tidak terlepas dari beberapa aspek. Pertama, dikaji dari aspek perumusan tujuan pembelajaran, sudah dikembangkan berdasarkan kompetensi atau kinerja yang harus dimiliki oleh mahasiswa. Rumusan tujuan pembelajaran selanjutnya diikuti oleh luasnya cakupan materi, sehingga ulasan materi mampu mendukung tercapainya tujuan pembelajaran. Selain kesesuaian cakupan materi, metode penilaian juga sudah berdasarkan rumusan kata kerja operasional indikator atau tujuan pembelajaran. Dengan demikian, metode penilaian tiap modul akan berbeda, sesuai jenjang kemampuan yang diukur. Kedua, dikaji dari aspek metode atau strategi penyampaian pesan, e-modul dinilai mampu memicu ketertarikan dan keterlibatan mahasiswa untuk belajar. Penyampaian materi berdasarkan karakteristik dan kompleksitas pengetahuan. Ketiga, dikaji dari aspek sajian tugas proyek, dinilai mampu mendorong pembelajaran yang menantang dan upaya kolaboratif sekaligus sebagai bagian dari penilaian. Hasil penelitian Bas (2011) menujukan bahwa proyek membuat mahassiswa termotivasi, 
membangun pengetahuan dengan menerima ide-ide yang berbeda, memahami sudut pandang orang lain, dan menegosiasikan solusi. Keterampilan ini yang diperlukan dalam dunia nyata, sehingga berimbas pada sikap positif mahasiswa terhadap pembelajaran.

Berdasarkan penilaian ahli media e-modul berada pada kategori sangat baik dengan perolehan persentase sebesar 90\%. Peroleh ini tidak terlepas dari beberapa aspek. Pertama, tampilan e-modul menggunakan sistem pengaturan dan kombinasi warna yang sederhana dan konsisten. Tampilan atau halaman e-modul mencakup halaman pembuka atau opening, halaman beranda, dan halaman isi. Desain tampilan halaman mengadopsi aturan perancangan visual yang dipublikasikan oleh Smaldino, Lowther, dan Russell (2008) dalam bukunya yang berjudul Instructional Technology \& Media for Learning. Pengaturan halaman menggunakan sistem perataan dan bentuk sajian mengikuti aturan sepertiga. Artinya layar dibagi tiga dan hasil pembagian disajikan objek berdasarkan hal yang difokuskan. Tampilan juga menggunakan prinsip keseimbangan yaitu unsur-unsur secara merata tersebar pada setiap sisi baik secara vertikal maupun horisontal. Pemilihan warna menggunakan prinsip roda warna sehingga terjadi kerharmonisan warna. Warna dominan yang digunakan adalah biru dan putih. Dua warna ini merupakan kombinasi warna yang disarankan. Prinsip kemudahan dibaca juga diterapkan ketika e-modul digunakan di layar komputer dan diproyeksikan dengan LCD. Kedua, unsur teks menggunakan gaya, ukuran, spasi, warna yang konsisten. Gaya teks menggunakan gaya yang polos yaitu tidak ada hiasan dan memilih gaya sans serif tipe arial. Tipe ini memiliki dua keuntungan yaitu terlihat jelas dan nyaman di mata ketika ditampilkan di layar komputer maupun ketika diproyeksikan menggunakan LCD. Ukuran teks menggunakan ukuran standar yaitu 11. Kejelasan teks ketika diproyeksikan difasilitasi dengan tool zoom (mengatur besar kecil tampilan teks) sehingga ukuran teks dapat diatur dan lebih fleksibel. Spasi teks menggunakan prinsip keterbacaan maksimum artinya baris-baris teks tidak terlalu rapat dan tidak terlalu longgar. Ketiga, sajian gambar menggunakan prinsip keterbacaan, posisi, dan ukuran. Keterbacaan gambar ditandai dengan resolusi gambar yang menggunakan resolusi standar sehingga tidak pecah. Posisi gambar diletakkan secara konsisten di sebelah kiri teks dan memperhatikan prinsip kedekatan. Prinsip kedekatan dimaksudkan untuk memudahkan siswa memproses informasi melalui teks dan gambar, sehingga proses kognitif tidak terpisah. Ukuran gambar menyesuaikan dengan ukuran halaman, sehingga sebaran teks dan gambar nampak proporsional.

Berdasarkan penilaian mahasiswa bawa e-modul berada pada kategori baik dengan perolehan persentase $85,77 \%$ hal ini tidak terlepas dari beberapa hal. Pertama, pemaparan isi e-modul jelas. Indikasi kejelasan ini nampak pada pemaparan materi menggunakan bahasa sederhana sesuai tingkat perkembangan mahasiswa, materi-materi psikomotor disertai contoh-contoh implementasi pada di lapangan, dan materi abstrak disajikan dengan media konkret seperti animasi dan video. Kedua, kualitas teknis khsusunya aspek tampilan dinilai menarik. Tampilan halaman dirancang sederhana agar tidak membingungkan siswa.

\section{SIMPULAN}

E-modul telah berhasil dikembangkan menggunakan model Dick dan Carey (2005). Model ini menuntun langkah-langkah pengembangan e-modul menjadi lebih sistematis serta meminimalkan terjadinya kesalahan pada setiap langkah pengembangan. Berdasarkan penilaian ahli, bahwa validitas isi e-modul memperoleh skor $92 \%$ yang berada pada kategori sangat baik, validitas desain pembelajaran memperoleh skor 93,91\% yang berada pada kategori sangat baik, dan aspek media memperoleh skor $90 \%$ yang berada pada kategori sangat baik. Berdasarkan penilaian mahasiswa bahwa e-modul berada pada kategori baik dengan skor 85,77.

\section{DAFTAR PUSTAKA}

Alias, Norlidah \& Saedah Siraj. 2012. Design and development of physics module based on learning Style and appropriate technology by employing isman Instructional design model. The Turkish Online Journal of Educational Technology. 11 (4), 84-93.

Asyar, H. R. 2011. Kreatif mengembangkan media pembelajaran. Jakarta: Gaung Persada.

Bas, G. 2011. Investigating the effects of project-based learning on students academic achievement and attitudes towards english lesson. The Online Journal of New Horizons in Education. 1(4). 1-15. Tersedia pada http://www.tojned.net/pdf/tojnedv01i04-01.pdf.

Borg, W. R. \& Gall, M. D. 2003. Educational research: an introduction (7th ed.). New York: Longman, Inc.

Buck Institute for Education. 2012. Project based learning for the 21st century. Tersedia pada http://www.bie.org/about/what is pbl. (Diakses tanggal 22 Maret 2017) 
Capraro, R. M. \& Slough, S. W. 2009. Project-based learning: An integrated science, technology, engineering, and mathematics (STEM) approach. Texas: Sense Publishers.

Dick, W., Carey, L., \& Carey, J. O. 2005. The systematic design of instruction. Boston: Pearson.

Feininger, Andreas. 1999. The Complete Photografer. Unsur Utama Fotografi. Di terjemahkan oleh Soelarko. Semarang: Dahara Prize

Gee, J. M. 2005. Learning by design: Good video games as learning machines. E-Learning. 2(1). 5-16. Tersedia pada http://www.wwwords.co.uk. (Diakses tanggal 25 Maret 2017).

Gewanda, Griand. 2003. Panduan Praktis Menciptakan Foto Menarik. Cetakan II. Jakarta : Puspa Swara

Maxwell, N. L., Bellisimo, Y., \& Mergendoller, J. 1999. Problem-based learning: Modifying the medical school model for teaching high school economics. Tersedia pada http://www.bie.org. (Diakses tanggal 20 Maret 2017). Pemula. Jakarta: PT. Gramedia Pustaka Utama

Prastowo, A. 2011. Panduan kreatif membuat bahan ajar inovatif. Yogyakarta: Dipa Press.

Pusat Pembinaan dan Pengembangan Bahasa. 1990. Kamus Besar Bahasa Indonesia. Jakarta: Departemen Pendidikan dan Kebudayaan

Sadiman, Arif S. dkk.2002 Media Pendidikan Pergertian, Pengembangan dan Pemanfaatannya. Cetakan kelima. Jakarta: PT. Raja Grafindo Persada.

Santyasa, I W. 2011. Pembelajaran inovatif. Bahan ajar. Singaraja: Undiksha.

Smaldino, S. E., Lowther, D. L., \& Russell, J. D. 2008. Instructional technology \& media for learning: Teknologi pembelajaran dan media untuk belajar. (Terjemahkan Arif Rahman). Jakarta: Kencana.

Soelarko, 1984. Fotografi Untuk Pelajar. Bandung : Binacipta

Suleiman, A.H. 1988. Media Audio-Visual Untuk Pengajaran, Penerangan dan Penyuluhan. Jakarta: PT. Gramedia

Sungkono. 2003. Pengembangan Bahan Ajar. Yogyakarta: FIP UN.

Suparman, M. A. 2012. Desain instruksional modern. Jakarta: Erlangga.

The George Lucas Educational Foundation. 2005. Instructional module project based learning. Tersedia pada http://www.edutopia.org/modules/PBL/ what pbl.php. (Diakses tanggal 20 Maret 2017). 